\title{
TOLERANCE AS AN IMPORTANT ASPECT OF CONFLICTOLOGICAL COMPETENCE FORMATION OF FUTURE FOREIGN LANGUAGE TEACHERS
}

\section{Ganna Polishchuk ${ }^{1}$}

DOI: https://doi.org/10.30525/978-9934-26-049-0-22

Abstract. The aim of this work is to study the level of tolerance in the process of conflictological competence formation of future foreign language teachers by the use of theoretical research methods (analysis of psychological and pedagogical literature, comparison); empirical; quantitative and qualitative data analysis. The features of the «tolerance» concept in the scientific sphere, its types and its determinants as a sociopedagogical phenomenon are clarified. The essence of the «pedagogical conflict» concept and the main causes of pedagogical conflicts are analyzed. The low tolerance level of both students and teachers is recognized as one of the main conflict causes in higher education institutions. As a result of the diagnostic examination of the motivational and value component of conflictological competence, the average level of students' tolerance was established, which testified to the prospects of further work in developing the orientation of future foreign language teachers to constructive conflict resolution, tolerant attitude, cooperation and search for compromise solutions.

\section{Introduction}

Complicated conditions of modern life, events that take place in the state and society, the devastating impact of the global coronavirus pandemic on the economy lead to exacerbation of social conflicts that directly affect the existence and development of all human life spheres, among which the education system is no exception. Thus, conflictological problematics are of particular importance in all spheres of professional training, which is exacerbated by a significant increase in the number of interpersonal

${ }^{1} \mathrm{Ph} . \mathrm{D}$ in Philology, Assistant Professor of the Chair of the English Language and its Teaching Methods, Volodymyr Vynnychenko Central Ukrainian State Pedagogical University, Ukraine 
conflicts in the education system and gives exceptional relevance to the conflictological competence formation of future foreign language teachers since pedagogical conflicts are a complex phenomenon, in which various social, psychological, pedagogical, value and personal factors intersect and provide influence on the personality of both the student and the teacher. The level of individual tolerance in resolving pedagogical conflicts is defined as an important aspect of conflictological competence formation of future foreign language teachers (which is defined as an integrated personal education based on a system of scientific knowledge about the conflict, skills, practical experience of conflict resolution, which are purposefully developed in such contexts of conflictological training of higher education institution as cross-cultural, communicative and intrapersonal). Because it is ethics and strategy of nonviolence, the idea of tolerance for other points of view, values, culture, the idea of dialogue and mutual understanding, the search for mutually acceptable compromises, as well as the most important values of tolerance - peace, acceptance of ethnic, political, religious, interpersonal differences, recognition of equal existence of the «other»provide a constructive conflict resolution in the education system.

In the modern scientific paradigm, the pedagogy of tolerance is studied by many both domestic and foreign researchers: Yuliia Todortseva [24], Halyna Bezyuleva, Halyna Shelamova [3], Valerii Talanov [23], Olha Akimova [2], Vladimir Gutu, Ioana Boghian [19], Ioana Boghian [27; 28] and others; tolerance is recognized as a value basis of teacher's professional activity [16]; a socio-pedagogical tool for conflict resolution [22]; it is also considered in the system of value purpose-oriented priorities of education [7], in the context of value self-determination of the students [13]; the tolerance formation of students in the educational space of medical higher education institutions is analyzed [6], etc. However, in modern science the issues of conflictological competence formation of future foreign language teachers, taking into account the importance of the students' tolerance level, are insufficiently studied, which allows for further scientific research. And since the main goal of the modern Ukrainian education system is to create conditions for the development and self-realization of the individual in higher education institutions, the formation of their key competencies, which will solve various problems in future professional activities (and since key competencies include conflictological competence), its development in 
future professionals becomes relevant at the present developmental stage of both the Ukrainian society and the higher education system. The relevance of tolerance level studying in the process of conflictological competence formation of foreign language teachers is beyond doubt, as specialists in this field of knowledge must not only master the knowledge of several languages, but also master the cultural heritage of different countries, realize and accept universal values that enable understanding and tolerance towards others, and a foreign language appears to be not only a means of communication but also opens new opportunities for the humanization of education, promotes tolerant interpersonal relationships between people of different nations and nationalities.

The aim of this work is to study the level of tolerance in the process of conflictological competence formation of future foreign language teachers by the use of theoretical research methods: analysis of philosophical, psychological and pedagogical research literature, comparison and generalization to study the state of the problem; substantiation of the conceptual and categorical apparatus; assessment and generalization of the facts collected in the research process to determine the features of conflictological competence formation of future foreign language teachers; empirical: observations, surveys, testing, questionnaires to diagnose the levels of tolerance; quantitative and qualitative analysis of experimental data. Adherence to the axiological approach (Renata Vynnychuk, Svitlana Vitvytska, Tetiana Kalyuzhna, Aida Kyriakova, Vasyl Kryzhko, Iryna Mamayeva, Milton Rokeach, etc.), which is considered in the psychological and pedagogical paradigm as a modern philosophical and pedagogical strategy, based on the idea of universal values priority and self-worth of each individual, determines the prospects for further improvement of the education system, and conflictological competence formation of future foreign language teachers using an axiological approach involves the development of such values like freedom, love and feeling of importance for other people, respect for human dignity, attitude to human as to the highest value, the pursuit of justice, the ability to empathize, and so on. The abovementioned value orientations of students, according to the concept of Aida Kyriakova [11], in later life are transformed into beliefs and characterize their orientation, which determines the behavior of people throughout life. It is important to emphasize that the axiological approach 
involves adherence to the pedagogical principle of tolerance, which should be taken into account in conflictological competence formation of future foreign language teachers since it involves treatment of human as the highest value, respect for human dignity, diverse opinions, positions and beliefs, the pursuit of justice, the capacity for compassion, overcoming conflict, taking into account the ethics of the relationship between the conflict parties.

\section{Pedagogical conflict}

It is obvious, that the existence of a modern higher school is impossible without pedagogical conflicts, as a clash of different interests, because the individual and psychological characteristics of the educational process participants create the preconditions for conflict situations among different categories of university staff. Failure to understand the real causes of conflict between teachers and students, students and students, management and subordinates in higher education institutions leads to prolonged pedagogical conflict and the manifestation of various negative consequences. Eduard Kirshbaum argues that from the beginning the pedagogical process has a given «conflictogenity» and is characterized by the role and positional asymmetry of its participants [12, p. 44]. The main conflict lines in higher education are the interaction of its participants at three levels: macrolevel («state») - «society - a higher education institution», meso-level («leadership») - «administration - the university, faculty, groups» and micro-level («personality») - «student - teacher», «teacher - teacher», «student-student». Based on the research, it is proved that $15 \%$ of teachers had conflicts on the line «teacher - administration of higher education institution», which is, according to Nina Pidbutska, due to the failure of one of the subjects of interaction to discharge their direct responsibilities, disagreement on making important decisions, inadequate assessment of performed work and negligent attitude to work, abuse of the position by the head of the institution, the use of subordinates' labor to achieve the head's goals. However, the main type of higher education conflict, according to the research by this scientist, is the conflict between student and teacher (45\% and 35\% respectively). Such conflicts in higher education institutions are explained by the fact that students often do not want to obey the will of the teachers, their orders, actively defend their own opinion, blame adults for all the troubles and misunderstandings [19, p. 146-147]. Overcoming 
these conflicts in the pedagogical process of higher education institutions contributes to the accumulation of some experience in protecting one's own rights at the state level, communicating with management, students and teachers. Alona Lukashenko comes to a similar conclusion: a specific feature of conflicts between teacher and adult participants of the pedagogical process is their high emotionality, conflict sharpness, excessive didacticism, rigid defense of their rights, unwillingness to compromise, which leads to destructive consequences for their participants, negatively affects the state of the moral and psychological climate. The causes of such conflicts are a combination of objective (current socio-economic condition of the institution, poor development of regulatory procedures for resolving contradictions, non-optimal functional relationships between teachers, incompetence of school management, etc.) and subjective (psychological incompatibility, as well as the presence of interpersonal conflicts between teachers, a significant number of teachers prone to interpersonal conflict due to a certain professional deformation of the teacher, which is manifested in the simplification of worldview and understanding of many problems, categorical assessments and judgments, rigid fixation in a professional position, feelings of self-sufficiency, «authority threat complex», emotional devastation, high anxiety, etc.) factors [15]. Thus, pedagogical conflicts are a complex phenomenon in which various social, psychological, pedagogical, value and personal factors closely intersect and provide influence on the personality of both the student and the teacher.

Liudmyla Podoliak and Viktor Yurchenko conclude that pedagogical conflict situations have distinctive peculiarities by their nature: the subjects of conflict situations are unequal in social status (teacher - student), which also determines different behavior; the subjects of conflict situations are unequal in life experience and age, they have different degrees of responsibility; the subjects of conflict situations are unequal in education, they have different understandings of phenomena and their causes; the subjects of conflict situations are unequal in their ability to solve life and professional problems [20]. But the most urgent source of conflict situations is considered to be the difference of value systems and principles that play an important role in regulating interpersonal and intergroup conflicts, namely: tolerance as respect and recognition of equality, rejection of domination and violence, prevention of discrimination against children $[29$, p. 1]; recognition of the 
multidimensionality of human culture, norms, beliefs, refusal to reduce this diversity to uniformity or to the advantage of one point of view, which should be the basis of the teacher's professional activity $[16, p .7]$.

\section{Tolerance}

Here is a brief description of this concept's essence. From ancient times to the present ones, the phenomenon of tolerance has been the subject of research in various fields of science, including philosophy, sociology, literature, pedagogy, psychology, medicine, etc. The content of tolerance as a universal value is revealed in the humanistic ideas of the Ukrainian philosophers, writers, teachers (Hryhorii Skovoroda, Taras Shevchenko, Lesya Ukrainka, Ivan Franko, Borys Hrinchenko, Vasyl Sukhomlynsky, Vasyl Symonenko, etc.), as evidenced by the author's statements, which have become aphorisms [6, p. 135].

The Declaration of Principles on Tolerance (Article 1) interprets tolerance as «respect, acceptance and appreciation of the rich diversity of our world's cultures, our forms of expression and ways of being human...; ... harmony in difference; ...virtue that makes peace possible, contributes to the replacement of the culture of war by a culture of peace...».

The key principles of tolerance are: equality between representatives of different nations, regardless of their sex, race, nationality, religion or belonging to any other group; mutual respect, friendliness, tolerant attitude of all members of society to representatives of other social, cultural, religious groups; refusal of violence; equal opportunities of all members for participation in the political life of society; the preservation and development of the culture and languages of national minorities guaranteed by law; the ability to follow the traditions of all cultures represented in society; freedom of religion; cooperation and solidarity in solving common problems [8, p. 175-180].

Among the types of tolerance, the researchers [16, p. 36-37] distinguish the following meaningful types: political tolerance as an attitude to the activities of various parties and associations; interethnic tolerance as an attitude to the representatives of different nations, the ability not to transfer the shortcomings and negative actions of certain members of the nationality to other people; racial tolerance as the absence of prejudice against members of another race; religious tolerance as a recognition of 
the religious peculiarities of different denominations; gender tolerance as an unbiased attitude towards members of the opposite sex; age tolerance as impartiality towards people of different ages; physiological tolerance as an attitude to the sick, disabled, people with external defects; educational tolerance as a broadminded attitude to the statements and behavior of people with low educational level by the more educated segments of the population; geographical tolerance as impartiality of the inhabitants of the capital to the inhabitants of small towns, villages and other regions and vice versa; interclass tolerance as a broadminded attitude to the representatives of different property strata - rich to poor, poor to rich; sexual orientation tolerance as a broadminded attitude towards people with non-traditional sexual orientation; marginal tolerance (tolerance towards marginalized members of society) as an attitude towards beggars, homeless people, prisoners, etc.

This study is focused on tolerance as a socio-pedagogical phenomenon in which researchers identify the following determinants, namely: psychophysiological (which should ensure psychological stability); psychological (which covers the qualities of personality); socio-pedagogical, which includes the formation and development of a certain social (professional, gender and other) role of the individual based on the positive values of the individual and society and types of personal tolerance, namely: interpersonal, social, socio-psychological, ethnic, communicative, political and others. According to Valentyna Pavlenko, Maia Melnychuk, in modern science tolerance is considered in two aspects: as synonymous for psychophysiological endurance, resilience and as a quality of personality that regulates the process of human interaction with the outside world, makes it more adequate and constructive. Accepting the point of view of these scientists, mature tolerance is acknowledged as not only psychological stability and endurance but also competence in a broadminded behavior, cognitive difficulty in perceiving a contradictory world, empathic readiness for «otherness», personal meanings, values, coexistence with the world [21, p. 25].

Thus, as a result of the content analysis of the tolerance phenomenon, the researchers concluded that the socio-pedagogical approach allows considering it in three main aspects, namely: in the integrative, substantive and regulatory aspects. It also allows to use it as a fundamental sociocultural norm in resolving conflict situations at the levels of «personality - 
personality» and «personality - society»; identify and solve problematic issues of human interaction in the spheres of society, which are characterized by relative secrecy and derivation [22, p. 153].

\section{Low level of tolerance as a cause of pedagogical conflicts}

The abovementioned facts allow us to consider the tolerance level of the future teacher in resolving pedagogical conflicts as an important aspect of conflictological competence formation of future foreign language teachers. Using the research of Iryna Nikulina, the views of students and teachers of higher education institutions on the causes of pedagogical conflicts are briefly summarized. As the author notes, according to the students, the most common causes of pedagogical conflicts are biased assessment and excessive meticulousness of the teacher, disregard of the students. In the students' opinion, conflict and non-conflict teachers differ from each other. Non-conflict teachers have authority in the student group, they are friendly, able to decentralize, tolerant of other people's shortcomings. The personal characteristics of the teacher can also be a cause of conflict: a mistake in choosing a profession; increased responsibility for the quality of education; dissatisfaction with the teacher's need for recognition by the students and teaching staff $[18$, p. 83$]$.

Symptoms of the teacher's intolerance are: ambitiousness; vigilance in communication; irritation; hypersensitivity; sharp emotional outbursts (indignation, hatred), discrimination of behavior; intimidation tactics; negative verbalization towards children; aggressive and hostile attitude towards the child. The meaning of the teacher's activity in the formation of tolerant relations is to increase the communicative competence of students, that is be ready and able to enter into dialogue, to seek the truth with others and to report the results of their search in a form understandable to everyone [16, p. 51].

The teachers are convinced that pedagogical conflicts arise due to violations of discipline in the classroom and rules of conduct in higher education institutions. This means that the causes of pedagogical conflicts lie in the field of didactic interaction: it is the dependent attitude of students to studying, laziness, unwillingness to learn, lack of interest in the future profession; discrepancy of the students' preparedness level to the level of the given educational process in higher education institutions; retention 
of students who are practically not studying; overestimated self-esteem of some students regarding their knowledge of the discipline [18, p. 83].

According to Iryna Nikulina, the causes of pedagogical conflicts are also determined by the personal qualities of students: infantilism, inappropriate behavior, aggressive manner of communication with the teacher. In the teachers' opinion, non-conflict student has the following qualities: politeness, tact; the ability to listen to another point of view and correct one's own behavior; honest and responsible attitude to learning; benevolence [17, p. 285].

According to Olha Yeremenko, in the educational space, the following contradictions that lead to the pedagogical conflict may arise from the position of teacher: dissatisfaction with the chosen profession; increased responsibility for the quality of education; responsibility for the life and health of students; dissatisfaction with the need for recognition, respect for the teacher by students; monotony of pedagogical activity, rigid planning and its strict observance within the given pedagogical system; use of traditional forms of teaching and assessment. Students are convinced that the contradictions are manifested in the following: the presence of age-sensitive periods that lead to changes in behavior, reactions to what is happening; disregard for the psychological, individual characteristics of the student's personality; dissatisfaction with the forms of material presentation; misunderstanding of the teacher's actions (as a consequence, the lack of a gender-oriented approach in interpersonal interaction) $[9$, p. 66-67]. It can be concluded that the causes of pedagogical conflicts in higher education institutions are determined by both objective (external environmental conditions) and subjective (features of a particular individual) factors. The causes of pedagogical conflicts can be divided into the following groups: socio-economic, related to the economic situation of the country and higher education institutions, the social status of teachers and students; socio-psychological - psychological fatigue and nervous overload, competition, lack of group cohesion, etc.; psychological - differences in interests, values, views, characters and temperaments of students; unwillingness or inability to understand the other, tactlessness in communication, overestimated or underestimated self-esteem; organizational and pedagogical - shortcomings in the organization of educational activities by students and teachers, low level 
of conflictological culture, tolerance, imperfection of methods, strategies and tactics of conflict prevention and resolution.

All of the abovementioned leads to a deterioration of the psychological climate between all participants of the conflict situation and the destruction of interpersonal relationships; reduction of productivity due to conflict; complication of cooperation and restriction of partnership possibilities between the parties during and after the conflict; deterioration of relations between the parties to the conflict; destruction of joint activities that existed before the conflict; stimulation of the inadequate well-being and various psychological defenses manifestation; growth of confrontation, which encourages people to fight and makes them seek victory more than searching an alternative [25, p. 23-24].

It is well known that in case of impossibility to prevent pedagogical conflict, it is expedient, from the pedagogical point of view, to recognize its beginning in time. Scientists emphasize the existence of certain signals that indicate the origin of the conflict and such signals include the following: crisis (during a crisis, the usual norms of behavior lose force, a person becomes capable of extremes - in one's own imagination or reality); misunderstanding (caused by the fact that a certain situation is associated with the emotional tension of one of the participants, which leads to distortion of perception); incidents (any trifle can cause temporary excitement or irritation, but passes very quickly); tension (a state that distorts the perception of another person and his actions, the relationship becomes a source of constant anxiety when any misunderstanding can escalate into conflict); discomfort (intuitive feeling, excitement, fear, which are difficult to describe in words) [4, p. 386]. Thus, such signals as crisis, misunderstanding, incidents, tension and discomfort indicate the existence of a conflict situation that can be resolved through individual work with specific teachers and students.

The scientists also point to the low conflictological and communicative competence of teachers and staff in higher education institutions in the structure of their professional competence. Valerii Agapov, Olha Belaia, Mariia Plugina, Liudmyla Kuleshova offer to create conditions in the educational environment to minimize the factors that contribute to pedagogical conflicts, as well as to work to improve the communicative and conflictological competencies of all subjects of the educational environment $[1$, p. 82]. Some work needs to be done in higher education institutions 
to eliminate the manifestations of conflictological incompetence of future teachers. Olena Borysova summarizes the most common manifestations of conflictological incompetence and states that the teachers are incompetent when they: 1) do not take into account the age psychological characteristics of students; 2) do not take into account the emotional and mental state of the child in a certain period; 3 ) focus the attention of the whole class on negative patterns of behavior; 4) do not know how to control their emotions and states (lack of emotional self-regulation skills); 5) are not able to resist child and adolescent provocations and manipulations [5, p. 29]. Thus, in the process of the studied phenomenon formation, the important factors for the future teacher are an acknowledgment of the age and individual characteristics of students, self-control of one's own behavior, knowledge of the child's psyche and modern methods of teaching and educating students, tolerance.

Of course, the pedagogy of tolerance requires the appropriate characteristics of the teacher. The main criteria of a tolerant personality of the teacher are the following: social activity; divergence of behavior - the ability to solve ordinary problems in a non-standard way; mobility of behavior - the ability to quickly change the strategy or tactics in the educational process, taking into account the circumstances; empathy - an adequate idea of what is happening in the inner world of another person; personality stability - the formation of socio-ethical motives of teacher behavior in the process of interaction with children, colleagues and parents [24, p. 19].

Tolerant teachers must be able to: analyze and predict the main results of their own professional and communicative activities; create and maintain a tolerant educational environment: identify the causes of conflicts in the student group; promptly identify means of their own psychological and pedagogical improvement and carry out their practical implementation; promote a tolerant relationship between students and their parents; coordinate the activities of all units and all subjects of the educational process in the educational institution, etc. [16, p. 19], and an important source of tolerance is pedagogical communication between teacher and student, when the first appears as a model, a standard of this quality manifestation in different situations: during classroom and extracurricular informal communication; during the management period of diploma, course, abstract works of students, during industrial practice, and also during disputes, creative meetings and scientific conferences [16, p. 81]. 


\section{Determination of the tolerance level}

In the context of this study, it is necessary to note the results of research conducted by Olena Lopez, Kseniia Olifirova on the factors that are prerequisites for the conflictological competence formation of a higher education institution graduate, namely: communicative potential, self-regulation and individual typology. Communicative potential, as the scientists prove, determines the presence of the following personality characteristics: a pronounced need for communication and a constant willingness to meet this need; the desire for trusting and open interaction with others; high level of the individual's self-criticism; propensity for active social contacts, sociability; possession of social self-control as a personally stable quality, which is manifested in the ability to recognize the behavior of another person and emotional expression, which allows the individual to be actively involved in the social situation. Individualtypological characteristics of the graduate's personality, which include protection from the stress factors of ordinary life situations, are based on self-confidence, optimism, activity and emotional stability in difficult stressful situations. The third factor important for this work - the factor of self-regulation - determines the readiness for a tolerant perception of social and cultural differences, respectful and caring attitude to historical heritage and cultural traditions; skills of recognizing other people's emotions and the ability to influence their emotional state; the orientation of the individual to a constructive conflict resolution [14, p. 83]. These factors are considered to be a clear reflection of the influence on the conflictological competence formation of future foreign language teachers. A significant communicative potential, which involves the desire for trusting and open interaction with people of different nationalities who speak foreign languages is of particular importance for future specialists in this profession. Because it is impossible without the ability to find common ground with these people, tolerant perception of social and cultural differences, their understanding, as it reduces the conflict likelihood in society and education.

In the process of selecting diagnostic tools for the practical part of this study, it was taken into account, as some scientists advise, that the diagnostic minimum should be structured by level of education and the target audience; methods should be easy to apply, common among the professional community and not require much time to be studied [10, p. 5-6]. 
Particular attention was drawn to the diagnostic techniques that made it possible to objectively assess the individual manifestations of the studied phenomenon, taking into account the component composition and indicators of conflictological competence of future foreign language teachers, namely: cognitive-reflexive component (presence of integrated knowledge in conflictology; readiness for a tolerant perception of social and cultural differences, respect for the historical heritage and cultural traditions of people of different nationalities; reflection of one's own behavior); motivational value component (focus on constructive conflict resolution; tolerance towards other people; emotional resilience in stressful situations; desire to cooperate and find compromise solutions) and operationalcorrective (the ability to design one's own interaction and resolve conflicts; the ability to influence the assessments and judgments of opponents; the possession of technologies and strategies for resolving conflicts; the ability to organize work in a post-conflict situation).

Thus, the test «How tolerant are you?» by Olha Tushkanova [26, p. 357-359] was used to analyze the tolerance level of future foreign language teachers within the study of the motivational value component of conflictological competence, which presupposes the formation of personal and professional qualities (reflection, sociability, tact, tolerance, emotional stability). The respondents (the students of the Ukrainian universities in the control and experimental groups) were asked to give truthful answers such as «yes» or «no» to the test questions. The total number of points obtained indicates the tolerance levels of the subjects: from 0 to 4 points - low level, from 6 to 12 points - average level; from 14 to 18 points - high level. The study on this test revealed the following results: $28.25 \%$ of respondents ( 89 people) showed a high level of tolerance, steadfastness of beliefs, the ability to defend them in combination with a critical attitude to their own thoughts and behavior, the ability to realize their mistakes; $57.46 \%$ of respondents (181 people) showed an average level of tolerance and proved the ability to defend their point of view and conduct a dialogue during the manifestation of sharpness and superiority in the process of communication with interlocutors, disrespect for them; $14.29 \%$ of students (45 people) showed a low level of tolerance, which was manifested in their rejection of compromise, stubbornness, intemperance in dialogue, the possibility of physical aggression. Further implementation of a comprehensive 
developmental program for conflictological competence formation (use of modern teaching methods (expert assessment, conversation, interviews, interactive methods, training exercises, arbitration method, discussions, debates); forms of training organization (problem lectures, mini-lectures, seminars and practical classes, consultations, self-study work, practice); modern technologies for overcoming conflicts (mediation, case studies or situational learning, training technologies)) allowed to record a slight increase in the percentage of people with high level $(+1.95 \%)$, due to their reduction at average $(-1.3 \%)$ and low $(-0.65 \%)$ levels. The vast majority of respondents in control groups were uncompromising, unappealable, stubborn and aggressive in actions and communication in conflict situations, did not care about the beliefs and arguments of the partners, tried to ignore, subdue them and impose their point of view, etc.

A similar tendency was also observed in the experimental groups, but the dynamics were more significant. Thus, after the introduction of a comprehensive developmental program in the experimental groups, the percentage of people with a high level of tolerance increased by $8.07 \%$ (from $27.33 \%$ before the experiment to $35.40 \%$ after). The dynamics at the average level was $-3.11 \%$ ( $58.39 \%$ before the experiment and $55.28 \%$ after), at a low level $-4.96 \%$ (14.28\% before the experiment and $9.32 \%$ after). In conflict situations, such respondents showed firmness in defending their beliefs, which was correlated with their tolerance. During the conflict, they were able to rationally analyze the beliefs of partners and perceive them. Respondents of the experimental groups perceived their own opinions critically and could reject them if they were wrong. While communicating, they showed respect for the other side of the conflict, tried not to offend or degrade.

Thus, if tolerance includes a large number of specific skills and abilities such as ability to tolerantly express and defend one's own position as a point of view; readiness for a tolerant attitude and perception of other people's opinions and assessments; ability to «interact with people of different views» and ability to negotiate (agree on positions, reach compromise and consensus); tolerant behavior in tense situations (with differences in views, clashes of opinions or assessments) [16, p. 62-63], then the main features of a tolerant personality should be: attitude to human as to the highest value, respect for human dignity, diverse opinions, positions and beliefs, pursuit of justice, ability to empathize, overcome conflict, taking into account the 
ethics of the conflicting parties, patience; attachment to other people; sense of humor; trust; endurance of differences (national, religious, etc.); ability to control oneself not only in conflict situations; friendly attitude to others; ability not to judge others; humanism; ability to listen to the interlocutor; curiosity; ability to empathize, which definitely need close attention and should be formed in the future foreign language teacher.

\section{Conclusions}

In the context of tolerance levels analysis in conflictological competence formation of future foreign language teachers, a positive dynamics of tolerance growth during the experiment in control groups of students was observed: $28.25 \%$ of respondents, who showed a high level of tolerance and the ability to realize their mistakes, increased their tolerance level $(+1.95 \%)$ due to their reduction of the average one $(-1.3 \%)$, where $57.46 \%$ of respondents showed the average level of tolerance and proved the ability to defend their point of view and conduct a dialogue in sharp, superior and disrespectful communication with interlocutors, and a low level (-0.65\%), where $14.29 \%$ of students showed a low level of tolerance, which was manifested in their rejection of compromise, stubbornness, intemperance in dialogue, the possibility of physical aggression. In the experimental groups of students, a significant positive dynamics was revealed after the introduction of a comprehensive developmental program: the percentage of people with a high level of tolerance increased by $8.07 \%$ (from $27.33 \%$ before the experiment to $35.40 \%$ after). But in general, the tolerance level of future foreign language teachers can be described as the average one, which requires purposeful work of teachers to increase the level of tolerant consciousness of students. This means that the strategy of nonviolence, tolerance of other positions, values, culture, the idea of dialogue and understanding, the search for mutually acceptable compromises, that provide a constructive conflict solution in the education system, will contribute to the conflictological competence formation of the students in resolving pedagogical conflicts.

There is no doubt that at the present stage of education development the pedagogical process of higher education institution requires immediate updating of the educational materials' content by the pedagogy of tolerance, which will create a conflict-free environment for both students and teachers, which will be the topic of our further scientific research. 


\section{References:}

1. Agapov V.S., Belaya O.P., Plugina M.I., Kuleshova L.N. (2017) Faktory konfliktogennosti sovremennoy pedagogicheskoy sredy vysshey shkoly [Conflict generating factors of contemporary pedagogical environment of high school]. Akmeologiya, 2: 79-83.

2. Akimova O.V., Tabatchenko T.S. (2013) Cognitive component of Tolerance in Pedagogic Education. The Education and science journal, 1(1): 42-57. https://doi.org/10.17853/1994-5639-2013-1-42-57 (in Russian)

3. Bezyuleva G.V., Shelamova G.M. (2002) Tolerantnost' v pedagogike [Tolerance in pedagogical sciences]. M.: APO. (in Russian)

4. Bilenjka O.B., Chajkivsjkyj T.V. (2013) Socialjno-pedaghoghichni konflikty u vyshhomu navchaljnomu zakladi - prychyny vynyknennja ta shljakhy rozv'jazannja [Socio-pedagogical conflicts in high educational establishment - the reasons and resolution]. Naukovyj visnyk NLTU Ukrajiny, 23.12: 385-389. (in Ukrainian)

5. Borisova E.S. (2017) Problema konfliktologicheskoy kompetentnosti v prostranstve obshcheobrazovatel'noy organizatsii [Conflictological competence in general education]. Izvestiya Samarskogo nauchnogo tsentra Rossiyskoy akademii nauk. Ser.: Sotsial'nye, gumanitarnye, mediko-biologicheskie nauki, 2(19): 28-32. (in Russian)

6. Bukhaljsjka S., Gholobosh Gh. (2019) Formuvannja tolerantnosti studentiv u vykhovnomu prostori medychnykh zakladiv vyshhoji osvity [The formation of students' tolerance in educational space of medical high school]. Nova pedaghoghichna dumka, 4 (100): 134-137. (in Ukrainian)

7. Gershunskiy B.S. (2002) Tolerantnost' v sisteme tsennostno-tselevykh prioritetov obrazovaniya [Tolerance in the system of value oriented priorities of education]. Pedagogika, 7: 3-13. (in Russian)

8. Deklaracija pryncypiv tolerantnosti (1999) [The Declaration of Tolerance principles]. Pedaghoghika tolerantnosti, 3-4: 175-180. (in Ukrainian)

9. Jerjomenko O.A. (2017) Konfliktologhichni kompetenciji v systemi «pedaghogh-student» [Conflictological competence in the system "teacher-student"]. Problemy inzhenerno-pedaghoghichnoji osvity, 54-55: 65-71. (in Ukrainian)

10. Zastosuvannja diaghnostychnykh minimumiv $\mathrm{v}$ dijaljnosti pracivnykiv psykhologhichnoji sluzhby [The application of diagnostic minimum in diagnosing the members of psychological service] (2018) / Za zagh. red. V. Gh. Panka. Kyiv: UNMC praktychnoji psykhologhiji i socialjnoji roboty. (in Ukrainian)

11. Kir'yakova A.V. (2009) Aksiologiya obrazovaniya. Orientatsiya lichnosti v mire tsennostey [Axiology of education. Orientation of personality in the world of values]. Moskva: Dom pedagogiki. IPK GOU OGU. (in Russian)

12. Krishbaum E.I. (1986) Psikhologo-pedagogicheskiy analiz konfliktnykh situatsiy v pedagogicheskom protsesse [Psychological pedagogical analysis of conflict situations in pedagogical process] (PhD Thesis), Leningrad.

13. Lozynsjka L. (2011) Problema tolerantnosti u konteksti cinnisnogho samovyznachennja studentiv-medykiv [The problem of tolerance in the context of value selfestimation of the students of the medical establishtments]. Pedaghoghika i psykhologhija profesijnoji osvity, 6: 21-28. (in Ukrainian) 
14. Lopes E.G., Oliferova K.A. (2017) Predposylki razvitiya konfliktologicheskoy kompetentsii u studentov [Preconditions of students' comflictological competence development]. Obrazovanie vzroslykh v usloviyakh sovremennosti: problemy i perspektivy. Obshch. red. M. A. Vorob'evoy. Ekaterinburg. (in Russian)

15. Lukashenko A.O. (2006) Pedaghoghichni umovy formuvannja konfliktologhichnoji kompetentnosti vchytelja zaghaljnoosvitnjogho navchaljnogho zakladu [Pedagogical conditions of formation of conflictological competence of the secondary school teacher] $(\mathrm{PhD})$ Kharkiv, Kharkivsjkyj nacionaljnyj pedaghoghichnyj universytet im. Gh.S. Skovorody.

16. Molchanova A.O. (2013) Tolerantnistj jak cinnisna osnova profesijnoji dijaljnosti pedaghogha [Tolerance as the basic value of professional activity of the teacher]. Kyjiv: Instytut pedaghoghichnoji osvity i osvity doroslykh NAPN Ukrajiny. (in Ukrainian)

17. Nikulina I.V. (2014) Prepodavatel' i student: prichiny vozniknoveniya konfliktov [The teacher and the student: the reasons of conflicts]. Modernizatsiya kul'tury: idei i paradigmy kul'turnykh izmeneniy. Samara: Samarskiy gosudarstvennyy institut kul'tury: 283-287. (in Russian)

18. Nikulina I.V. (2016) Fenomenologiya pedagogicheskikh konfliktov [Phenomenology of pedagogical conflicts]. Vestnik Samarskogo un-ta. Ser: Istoriya, pedagogika, filosofiya: 82-86. (in Russian)

19. Pidbucjka N.V. (2010) Osoblyvosti konfliktiv u navchaljno-vykhovnomu procesi vyshhykh navchaljnykh zakladiv [The peculiarities of conflicts in educational process of high educational establishments]. Naukovyj visnyk $M D U$ imeni V.O. Sukhomlynsjkogho. Ser:: Pedaghoghichni nauky, (1.31): 143-150. (in Ukrainian)

20. Podoljak L.Gh., Jurchenko V.I. (2006) Psykhologhija vyshhoji shkoly [Psychology of high school]. Kyiv: TOV «Fil-studija». (in Ukrainian)

21. Pavlenko V.M., Meljnychuk M.M. (2014) Psykhologhija tolerantnosti osobystosti (na materiali doslidzhennja studentiv) [The psychology of tolerance]. Poltava: FOP Myron I.A. (in Ukrainian)

22. Serghijenko T.M., Samojlova Ju.I., Denysjuk Ju.I. (2020) Tolerantnistj jak socialjno-pedaghoghichnyj instrument vyrishennja konfliktnykh sytuacij [Tolerance as socio-pedagogical instrument of conflict resolution]. Innovacijna pedaghoghika, 22(2): 153-156. URI: http://dspace.univd.edu.ua/xmlui/handle/123456789/9242 (in Ukrainian)

23. Talanov V. (2000) Pedagogika tolerantnosti [Pedagogy of Tolerance]. Vysshee obrazovanie v Rossii, 2: 5-17.

24. Todorceva Ju.V. (2004) Pedaghoghika tolerantnosti [Pedagogy of Tolerance]. Odesa: SVD Cherkasov M.P. (in Ukrainian)

25. Trukhan M.A. (2016) Formuvannja ghotovnosti majbutnikh socialjnykh pedaghoghiv do dijaljnosti z rozv'jazannja profesijnykh konfliktiv u zakladakh osvity [The formation of future social teachers' readiness to conflict resolution diagnosis in high educational establishments] ( $\mathrm{PhD}$ Thesis), Khmeljnycjkyj. (in Ukrainian) 
26. Tushkanova O.I. (2002) Naskol'ko Vi terpimy? Tolerantnoe soznanie i formirovanie tolerantnykh otnosheniy (teoriya i praktika) [How tolerant are you? Tolerant conscious and formation of tolerant relationships]: sb. nauch.-metod. st. Moskva: [b. i.]: 357-359. (in Russian)

27. Boghian, I. (2016) Teachers' Perspectives on tolerance education. A Literature review. Journal of Innovation in Psychology, Education and Didactics, 20(2): 136-142.

28. Boghian, I. (2017) The values of tolerance education. A literature review. Journal of Innovation in Psychology, Education and Didactics, 21(2): 205-220.

29. Gutu, V., \& Boghian, I. (2019) A Bidimensional Psycho-pedagogical Model for Tolerance Education. Revista Romaneasca Pentru Educatie Multidimensionala, 11(4): 01-16. doi: 10.18662/rrem/153 